Article

\title{
Effect of Land Acquisition and Compensation on the Livelihoods of People in Quang Ninh District, Quang Binh Province: Labor and Income
}

\author{
Tran Tuan NGUYEN ${ }^{1,2, *}$, Gábor HEGEDÛ́ ${ }^{1}$ and Tien Long NGUYEN ${ }^{3}$ \\ 1 Department of Economic and Social Geography, University of Szeged, H-6722 Szeged, Hungary; \\ hegedusg@geo.u-szeged.hu \\ 2 School of Agriculture and Natural Resources, Vinh University, Vinh 461010, Nghe An, Vietnam \\ 3 Quang Ninh Land Fund Development Center, Quang Binh 510000, Vietnam; longgiahung@gmail.com \\ * Correspondence: nguyentrantuandhv@gmail.com
}

Received: 10 April 2019; Accepted: 4 June 2019; Published: 5 June 2019

\begin{abstract}
Researchers and development practitioners have an interest in the relationship between land and rural livelihoods. In this context, agricultural land is being increasingly lost because of developing industrialization in the provinces of Vietnam. The livelihoods of people, whose land is appropriated, are affected. Therefore, this article investigates the impact of land acquisition and compensation on the labor and income of people when the State acquires their land to construct Industrial park projects. For the research methods, secondary data from select governmental agencies were gathered, and 50 households were interviewed to collect primary data. The results of this research indicated that although household livelihoods have been reconstructed after land acquisition, many issues are also emerging that may challenge equitable and sustainable development. These include a high proportion of households with insufficient employment, as well as those that are spending compensation money in ways that do not generate income.
\end{abstract}

Keywords: land recovery; land transformation; land conversion; industrial park; Vietnam

\section{Introduction}

Land is the main means of livelihood in any agricultural economy [1]. Land conversion is a method where land is modified from agricultural to urban uses, and is a development that seems almost inevitable during periods of economic development and growth [2]. Much debate has taken place about whether or not to maintain or convert agricultural land to other uses. These debates include the perspectives of rural and urban supporters. From the viewpoint of rural supporters, land conversion has a negative impact, for example, the loss of agricultural land will lead to agricultural underemployment and waste of investment in irrigation infrastructure. Furthermore, not only can agricultural products be affected, but food security will also be threatened. Rural supporters believe that if the supply of food is to meet demand, the amount of agricultural land should be maintained. On the opposite side, urban supporters agree that land conversion is a reasonable result of industrialization and modernization. They argue that enhancing and manufacturing technology can solve the decline in agricultural production. Hence, the conversion of land is not seen as a threat from their viewpoint $[3,4]$.

Industrial development is considered to be a critical solution to help economic growth and increase living standards for urban areas. In addition, it also promotes the progress of local government officials. Low land prices have encouraged local governments to recover land for industrial development with the hope of attracting industrial investment into the locality [5]. Firman (2000) [6] discovered that industrial property development, in particular areas around Jakarta, was a major factor in the conversion of most farmland in Indonesia. Land conversion has led to other shifts, especially the 
structural shift from an agricultural economy to activities of industry and service. Moreover, this shift is also shown by the labor structure, which requires labor to have a higher degree of qualification as well as a higher working capacity. Meanwhile, not only in Indonesia but also in China, the industrialization process is often synchronous with urbanization and therefore, the conversion of agricultural land has taken place [7].

As a result, it can be said that along with the industrialization-modernization process, urbanization is the method of development of all countries, including Vietnam. Since the seventh Party Congress (1991), and especially since the eighth Party Congress (1996), the Government of Vietnam has outlined a plan to turn Vietnam into an industrial country by 2020. The question at that time was how to transform the traditional agricultural economy into a modern industrial one. In order to answer this question, the state-party sees the need to create space for industrialization and urbanization by converting agricultural land [8].

In the process of urbanization and industrialization, the process of social development has undergone a radical change through the formation of industrial parks instead of agricultural land. In order to create a land bank for the urbanization process, land acquisition and land clearance for the construction of industrial parks is required. Nevertheless, diverting land from agriculture to non-agriculture should be preceded by a significant shift in the labor force and local population [9]. Land acquisition also significantly reduced farmers' incomes, although they tried to increase income from other sources. In India, non-agricultural workers were less adversely affected than agricultural laborers, and the average impact on all workers was negligible [10]. Nevertheless, compulsory land acquisition and land transfer for businesses leads to large-scale unemployment and displacement and raises many questions about the goals and process of establishing special economic zones [1].

According to the report of the Department of Economic Zone Management, Ministry of Planning and Investment (Vietnam), in the first six months of 2018, industrial parks (IPs) and economic zones (EZs) attracted 445 newly registered foreign investment projects (FDI) and adjusted capital increase with total registered investment capital of nearly \$7 billion USD. They also attracted 259 newly registered domestic investment projects (DDI) and adjusted capital increase with total new investment capital of about 46,000 billion VND (nearly 2 billion USD). This report indicated that as of June 2018, Vietnam had 325 industrial parks with nearly 95,000 ha, in which 231 IPs had come into operation and 94 IPs were in the stage of compensation and clearance [11]. It can be seen that the demand for land is increasing, especially for the industrial zone.

Agricultural land shrinkage due to industrialization and modernization has a negative impact on the livelihood strategies of people, who depend on agricultural land or other natural resources. Farmland is very important for the livelihoods of most rural people in Vietnam [12]. In 2017, 68\% of the labor force was engaged in agriculture [13]. Ha Thanh Nguyen Thi (2011) [14] indicated that the need to convert a large amount of agricultural land into industrial, commercial, and residential land has raised many issues such as labor conversion, reduced traditional food production, the need for compensation, and future risk. Phuc Nguyen et al. (2016) [15] also concluded that equitable development and sustainable livelihoods were a challenge in Hue's periphery in the long term.

In fact, after land acquisition, up to $67 \%$ of agricultural workers still retained their old jobs. The number of peasants transferred to new jobs was $13 \%$ and $25 \%-30 \%$ had no or not enough employment. This was the situation of $53 \%$ of the people, whose land was recovered, who had lower incomes than before. On average, after land loss, each household had 1.5 laborers who were unemployed. For every hectare of agricultural land, there were 13 unemployed laborers who had to find ways to change their jobs [16]. Therefore, it can be said that agricultural land acquisition has a significant impact on poor households in rural and peri-urban areas of Vietnam. Moreover, livelihoods of rural households have been faced with the challenge of losing arable land on a large scale. A typical example of this is India [17]. Although the urban population is large, India is still a land of villages, where nearly $70 \%$ of the population lives in rural areas operating in agricultural production [18]. 
In 2017, the agricultural sector contributed about $15.4 \%$ of the nation's gross domestic product (GDP) but participated in nearly $62 \%$ of the workforce [19].

Concerning our case study of Vietnam, Quang Binh is a province located in the North Central part of Vietnam. Quang Binh province has the Cha Lo international border gate and some other auxiliary border gates connected with Laos. Thus, this province has advantages in trade with other provinces in the country and abroad. According to the Quang Binh Economic Zone Management Board, until 2017, industrial parks and economic zones of the province had attracted 94 projects, with a total registered capital of over 43,000 billion VND (nearly $\$ 1.8$ billion USD), in which there were four projects with foreign investment with a total registration of \$26 million USD [20].

With such a large demand, land acquisition for implementing these projects is inevitable. However, whether or not the implementation process, as well as the results of land acquisition are meeting the expectations of the people is still a question that needs to be answered. This paper will show the effects of land acquisition and compensation on the employment and income of people whose land was acquired for the construction of an industrial park project in Quang Ninh district, Quang Binh province.

\section{Database and Methodology}

\subsection{Research Area}

Quang Ninh occupies an area of $1191 \mathrm{~km}^{2}$ in Quang Binh province, located in the North Central region of Vietnam. This district is in the Southern gateway of Dong Hoi city with North-South traffic routes that include roads and railways. As such, Quang Ninh district has many favorable opportunities for economic development. In 2017, the population of Quang Ninh district was 89,062 people and the average population density was 75 people per square kilometer. This affects the investment planning and socio-economic development of the region. The economic structure of industries has shifted in the region. According to the Quang Ninh District Statistical Office [21], between 2014 and 2017, the construction industry and trade-services sector showed slight growth, whereas the agricultural sector decreased from $45.4 \%$ to $42.3 \%$. However, the district's economy still relies heavily on agricultural production, which accounts for nearly $50 \%$.

The Northwest Quan Hau Industrial Park project with an area of 250 ha, is one of four industrial zones in Quang Binh province prioritized for development. This project is also in alignment with the Vietnam industrial zone development plan for 2020 [21]. Phase one of the project has implemented land clearance and land acquisition with an area of 62.28 ha with compensation and support amounting to about 25 billion VND (more than \$1 million USD) from 2012 to 2017 [22]. Land acquisition for industrial park projects is a very difficult task. With a large acquired area, the number of affected households is also large. The time to implement the project is prolonged and deployed in stages. For this type of project, as well as the implementation of the land clearance policy for the project, the project changes according to the periods of the Land Law and the State's policies, so it has different impacts on the lives of people whose land was acquired.

Although the project has been approved by the State since 2010, this Industrial Park is still unfinished, and all but abandoned, having never had any investment from investors (except financial support from the State). Although, on the face of it, the project has many development advantages, it has not attracted investors. Financial capital is the cause of this problem. According to the Deputy Head of the Quang Binh Economic Zone Management Board, in order to invite investors, industrial zones must have adequate and modern infrastructure. Nevertheless, the project is still based on the capital supported by the State. To date, the State has provided 70 billion VND ( $\$ 3$ million USD) for the construction of infrastructure for this Industrial Park [23]. It can be said that this project is not working well as it has triggered negative consequences for people involved in land acquisition, for example, they have not been able to find new employment due to the lack of planning of the Industrial Park. Moreover, land within the planning area may cause difficulties for local people, as they can hardly 
invest in or improve their land for any purpose. Hence, the question is: with the prolongation of the land acquisition process, how will the livelihoods of people, whose land was acquired, be affected? In order to answer this question, the authors interviewed 50 of 310 land-loss households in the studied area to understand the impacts of land acquisition on their livelihoods.

\subsection{Methodology}

In this research, secondary data was gathered from several State Agencies, such as the Department of Natural Resource and Environment, Land Fund Development Centre, Compensation Branch in Quang Ninh district and Quang Binh province. Moreover, field research was carried out between February and March 2017. The data were collected through a variety of methods including documentary research and three key informant interviews. We conducted interviews with government officials at different levels and leaders of the Department of Natural Resource and Environment. In addition, our participants were interviewed with a semi-structured interview method and an in-depth interview method, which provided rich data for the analysis process. For reasons of quality rather than quantity, household surveys were conducted for 50 households out of a total of 310 affected households, whose land had been acquired. The sampling procedure was simple random sampling, which is a kind of representative sampling. Households were randomly selected based on the land acquisition decision lists provided by local authorities, which were accurate according to our fieldwork. Then, the authors used simple randomly generated selection in the case of each chosen unit in the overall sample. Computers were used to select these random units. The households were quite homogeneous in terms of the characteristics being studied. Thus, simple random sampling was considered as suitable for this study. The questionnaire had two main parts. The first part focused on the information of land acquisition and compensation, whereas the second part concentrated on the income and assets of the surveyed households. Furthermore, as none of the households kept written records about the information asked of them, this inevitably required the respondents to recall historical details from memory.

Based on the collected data and results of the survey, we conducted a general selection and analysis of research-related information. Therefore, Excel software was used for statistics and comparison. Results of the survey were also tabulated so that we could evaluate and explain these results. We also used ArcGIS software to make a map of the location of the Northwest Quan Hau Industrial park project. This helps readers to easily visualize the geographical location of the project.

\section{Results and Discussion}

The total area of acquired land to implement the project of the Northwest Quan Hau Industrial Park is 138.8 ha in the areas of Vinh Ninh, Luong Ninh, and Quan Hau Towns (Figure 1). With the finalization of land acquisition in December 2017, the project has acquired five tranches. Acquired land is mainly part of the project's roads with a total acquired area of 62.3 ha with a total compensation amount of 25 billion VND (more than \$1 million USD) [24]. Details are shown in Table 1. 


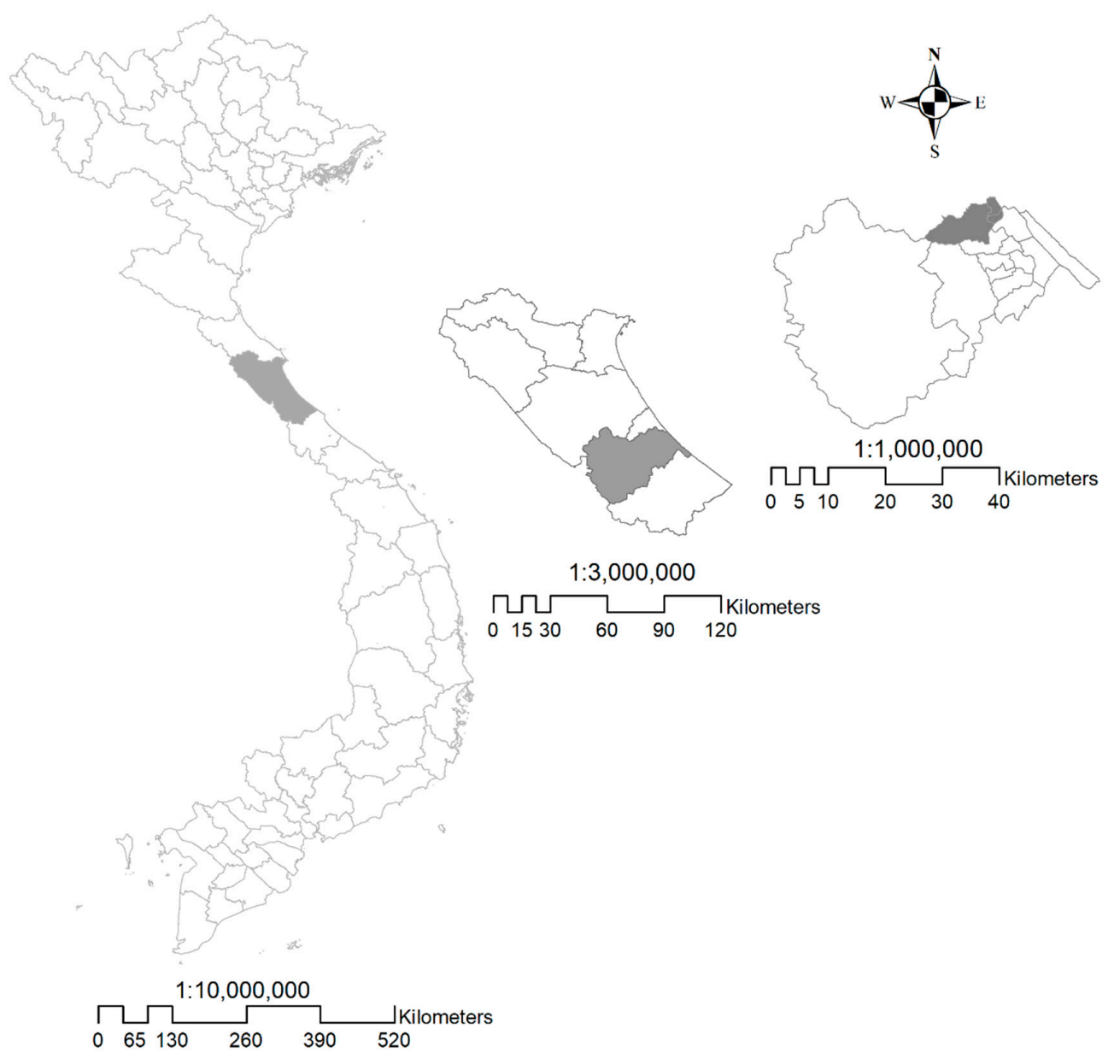

Figure 1. Location of Quang Ninh district and the project. Source: Tran Tuan NGUYEN.

Table 1. The information on land acquisition for the project of Northwest Quan Hau Industrial Park (until December, 2017).

\begin{tabular}{cccc}
\hline No & Types of Recovered Land & Area (ha) & Percent (\%) \\
\hline $\mathbf{1}$ & Agricultural land & $\mathbf{3 1 . 3 3 6}$ & $\mathbf{5 0 . 3 1}$ \\
\hline 1.1 & Land for agriculture production & 15.148 & 24.32 \\
\hline 1.1 .1 & Land for rice cultivation (LUC) & 4.977 & 7.99 \\
\hline 1.1 .2 & Other rice land (LUK) & 2.352 & 3.78 \\
\hline 1.1 .3 & Land with other annual crops (BHK) & 7.819 & 12.55 \\
\hline 1.2 & Forestry land & 15.804 & 25.37 \\
\hline 1.2 .1 & Land with planted forests for production (RST) & 15.804 & 25.37 \\
\hline 1.3 & Aquaculture land (NTS) & 0.384 & 0.62 \\
\hline $\mathbf{2}$ & Non-agricultural land & $\mathbf{3 0 . 9 4 4}$ & $\mathbf{4 9 . 6 9}$ \\
\hline 2.1 & Land for cemeteries and graveyards (NTD) & 14.174 & 22.76 \\
\hline 2.2 & Land for production and business establishments (CSK) & 15.3 & 24.57 \\
\hline 2.3 & Land for traffic (DGT) & 1.47 & 2.36 \\
\hline & TOTAL & $\mathbf{6 2 . 2 8}$ & $\mathbf{1 0 0 . 0 0}$ \\
\hline
\end{tabular}


When the State conducts land acquisition, it leads to changes in the livelihoods of people, especially farmers, who depend on agricultural activities. With the acquisition of agricultural land accounting for over $50 \%$ of total acquired land, this could lead to a shortage of productive land, labor surplus, unstable income, and other changes to people's lives.

Following Table 2, with the majority of agricultural land acquired, the proportion of agricultural workers has decreased rapidly by more than $25 \%$. Instead, other non-agricultural occupations after land acquisition have increased, especially in small business, with service and hired labor accounting for $17.6 \%$ and $16.5 \%$, respectively. Thus, the shift in labor and the change in industry to adapt to the land acquisition for implementing projects were relatively fast. In order to achieve this positive movement, the most important part is maintaining a sense of self-management, self-adaptation, and the ability for people to find jobs for themselves. This is reflected in the indicators of small traders and services, where the number of workers has increased. This is a spontaneous phenomenon, but it is also a way to reduce the local unemployment rate under the impact of industrial zone development and urbanization.

Table 2. The change in labor structure before and after land acquisition.

\begin{tabular}{|c|c|c|c|c|c|c|c|}
\hline \multirow[t]{2}{*}{ No } & \multirow[t]{2}{*}{ Survey Indicators } & \multirow[t]{2}{*}{ Unit } & \multicolumn{2}{|c|}{$\begin{array}{l}\text { Before Land } \\
\text { Acquisition }\end{array}$} & \multicolumn{2}{|c|}{ After Land Acquisition } & \multirow{2}{*}{$\begin{array}{c}\text { Increase/Decrease } \\
\text { Ratio (\%) }\end{array}$} \\
\hline & & & Total & Ratio (\%) & Total & Ratio (\%) & \\
\hline 1 & Number of surveyed households & Household & 50 & & 50 & & \\
\hline 2 & Number of people & Person & 315 & & 316 & & \\
\hline 3 & Number of people of working age & Person & 168 & 100 & 182 & 100 & \\
\hline 3.1 & Farmers & Person & 105 & 62.50 & 66 & 36.26 & -26.24 \\
\hline 3.2 & Handicraft industry & Person & 6 & 3.57 & 11 & 6.05 & 2.48 \\
\hline 3.3 & Small business, service & Person & 15 & 8.93 & 32 & 17.58 & 8.65 \\
\hline 3.4 & Staff and workers & Person & 12 & 7.14 & 15 & 8.24 & 1.1 \\
\hline 3.5 & Workers in industrial zones & Person & 5 & 2.98 & 12 & 6.59 & 3.61 \\
\hline 3.6 & Hired labor & Person & 16 & 9.52 & 30 & 16.49 & 6.97 \\
\hline 3.7 & Working outside the locality & Person & 9 & 5.36 & 16 & 8.79 & 3.43 \\
\hline
\end{tabular}

Source: Synthesized from the survey results in 2017.

Table 3 illustrates the employment situation of households after land acquisition. This situation tended to be positive, with nearly $50 \%$ of households having jobs. However, the number of households with insufficient jobs still accounted for a high proportion (32\% in Categories 2 and 3). This rate was largely due to differences in the working age structure of households. For households with a lower average working age, it was easier for individuals to find a new job to stabilize their family livelihoods. This result can be explained through the argument below.

Table 3. Employment situation of households after land acquisition.

\begin{tabular}{cccc}
\hline No & Categories & $\begin{array}{c}\text { The Number of Households } \\
\text { (Household) }\end{array}$ & Ratio (\%) \\
\hline 1 & Number of households with enough jobs & 22 & 44.00 \\
\hline 2 & Number of underemployment households & 13 & 26.00 \\
\hline 3 & Number of households without jobs & 3 & 6.00 \\
\hline 4 & $\begin{array}{c}\text { Number of households unchanged before } \\
\text { acquisition }\end{array}$ & 12 & 24.00 \\
\hline & TOTAL & $\mathbf{5 0}$ & $\mathbf{1 0 0}$ \\
\hline
\end{tabular}

Source: Synthesized from the survey results in 2017. 
The locality has no agricultural land reserves to compensate, hence, when the State acquires land to implement projects, the most common compensation method is cash. Along with the process of converting land from agriculture to non-agriculture, the implementation of compensation policies for land-loss people has significant impacts on the labor and employment issues of the people. Survey data showed that agricultural workers have a high average age (Figure 2). This is one of the reasons that the minority of agricultural workers want to invest in education to change their careers after land acquisition.

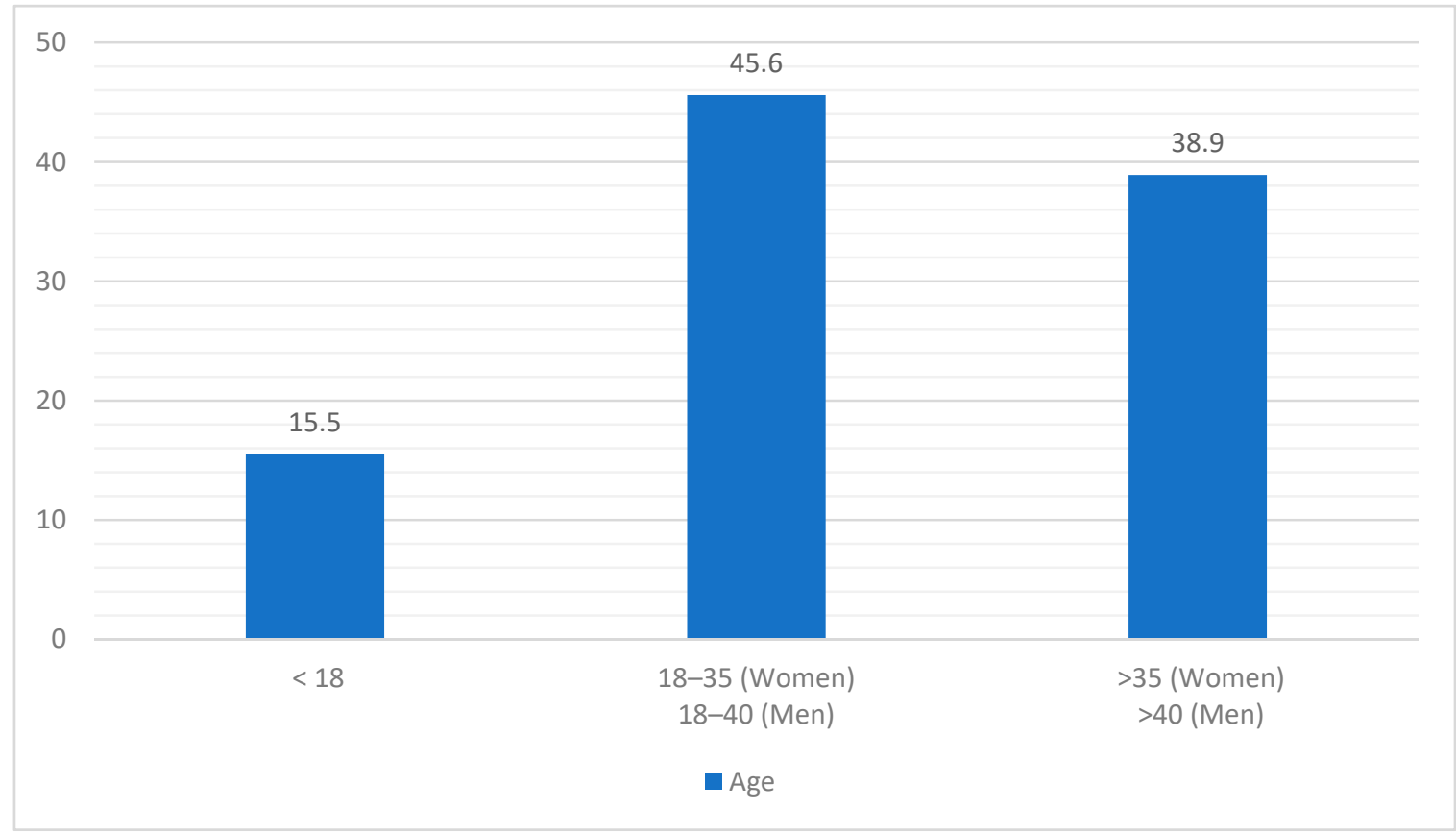

Figure 2. Working age in agriculture. Source: Synthesized from the survey results in 2017.

The change in land resources, which is the main production material of households, leads to changes in the income of households. The survey results showed that the household income from agriculture after land acquisition decreased significantly by $27.3 \%$, while the household income from services and business increased significantly between $13.9 \%$ and $35.2 \%$ compared to before land acquisition (Table 4).

Table 4. The structure of household income.

\begin{tabular}{cccccc}
\hline \multirow{2}{*}{ No } & $\begin{array}{c}\text { Source of Income } \\
\text { from Industries }\end{array}$ & $\begin{array}{c}\text { Before Land Acquisition } \\
\text { Income/Household/Month } \\
\text { (USD) }\end{array}$ & $\begin{array}{c}\text { Average } \\
\text { Structure (\%) }\end{array}$ & $\begin{array}{c}\text { After Land Acquisition } \\
\text { Income/Household/Month } \\
\text { (USD) }\end{array}$ & $\begin{array}{c}\text { Average } \\
\text { Structure (\%) }\end{array}$ \\
\hline $\mathbf{1}$ & Agriculture & 165.17 & 62.50 & 138.61 & 35.21 \\
\hline 2 & Handicraft & 10.69 & 4.05 & 22.25 & 138.52 \\
\hline 3 & Business, service & 36.60 & 13.85 & 44.67 & 35.19 \\
\hline 4 & Wage & 26.73 & 10.11 & 49.58 \\
\hline 5 & Hired wage & 25.09 & 9.49 & $\mathbf{3 9 3 . 6 3}$ \\
\hline
\end{tabular}

Source: Synthesized from the survey results in 2017. (These incomes are to be understood originally in VND, and they were converted to USD. The effects of inflation were ignored during the comparison.).

The main reason for this change was that households, whose land was acquired, reserved a part of the compensation for investment in the transportation business, trading business, and other services. Along with the change in income structure from agricultural to non-agricultural activities to suit 
the local development situation, the average income of households tended to increase compared to before land acquisition. However, there were still some households saying that their income after land acquisition was lower than before because they did not know how to use the compensation for any business purpose. This problem resulted in unstable situations for people's life-long livelihoods.

According to the results of the survey on households' use of compensation, $70 \%$ of households used the money for shopping purposes. When conducting an in-depth investigation of the assets owned by households before and after the recovery, more details about the use of those funds were obtained (Table 5).

Table 5. Property owned by the surveyed households.

\begin{tabular}{|c|c|c|c|c|c|}
\hline No & Categories & Unit & $\begin{array}{l}\text { Before Land } \\
\text { Acquisition }\end{array}$ & $\begin{array}{l}\text { After Land } \\
\text { Acquisition }\end{array}$ & Increase/Decrease \\
\hline & Total of Households & Household & 50 & 50 & \\
\hline 1 & Temporary house ${ }^{1}$ & Item & 3 & 0 & -3 \\
\hline 2 & Four-level house ${ }^{2}$ & Item & 28 & 22 & -6 \\
\hline 3 & Three-level house $^{3}$ & Item & 19 & 28 & 9 \\
\hline 4 & Tractor & Item & 4 & 2 & -2 \\
\hline 5 & Motorbike & Item & 40 & 58 & 18 \\
\hline 6 & Gas stove & Item & 18 & 32 & 14 \\
\hline 7 & Television & Item & 42 & 62 & 20 \\
\hline 8 & Fridge & Item & 16 & 31 & 15 \\
\hline 9 & Landline phone & Item & 16 & 22 & 6 \\
\hline 10 & Mobile phone & Item & 45 & 66 & 21 \\
\hline 11 & Computer & Item & 9 & 23 & 14 \\
\hline 12 & Washing machine & Item & 5 & 16 & 11 \\
\hline
\end{tabular}

Source: Synthesized from the survey results in 2017. ${ }^{1}$ Temporary houses are constructed with temporary materials such as bamboo and wood. Surrounding the house is the earth wall and the roof is recovered by leaves or straw; ${ }^{2}$ Four-level houses are built with bricks and wood. Maximum use life is 30 years. The roof is covered with tiles; ${ }^{3}$ Three-level houses have a bearing structure combined with reinforced concrete and bricks. The shelf life is over 40 years. The interior and exterior are finished.

In general, the use of compensation for households seems unreasonable to us. The percentage of households interested in investing in production, business, and education for their children was not low, but the amount of investment still accounted for a small proportion compared to the amount used for construction and renovation of houses. This is a common phenomenon in Vietnam. With that amount of compensation, households are able to develop production or businesses or apprenticeships to create a stable income to ensure livelihoods after losing much of their agricultural land. Nevertheless, it is the use of compensation money that leads to the fact that many households, after the acquisition, are only able to sustain their basic needs but not accumulate wealth. Some households rely on money earned from hired jobs to live, their income is unstable, and hence, their lives are not as stable as before.

In short, when the State acquired agricultural land, it greatly affected people's livelihoods. Source of capital that support livelihoods, such as natural, social, physical, and financial capital, change, and most are transferred from natural to financial and physical capital, with a few cases turning into human capital. In general, the circulation of source of capital with the current conditions is unable to support people's livelihoods in a sustainable manner.

Although household livelihoods have been reconstructed after land acquisition, many issues are nevertheless emerging that may challenge equitable and sustainable development. It is easy to see from the survey that in spite of an increase in employment opportunities, a limited number of farmers were successful in reconstructing their livelihoods. Additionally, much of the compensation received was invested in housing and family furniture, while little was spent on income-generating activities.

In order to solve the above problems, the authors propose some solutions as follows: 
Firstly, policy is one of the most important solutions to these problems. It is necessary to research and set up a fund to support jobs and stabilize life for people whose land is acquired; the fund should be formed from a part of land use levies and land taxes paid into the State budget by enterprises that use the land. The regulations on the responsibilities of State agencies at all levels related to the issue of job change and training for people are also a crucial policy. The project owners should have a priority regime for recruiting workers from households in the area of agricultural land acquisition to work in factories to help people stabilize income after agricultural land is reduced.

Secondly, the locality needs to review the approved land use planning to investigate, plan training, and change trades for people before land acquisition. This plan would ensure that people, whose land was acquired, can find a new career and stabilize their lives as quickly as possible. Moreover, local authorities and investors must actively guide people to use compensation money to enhance their job prospects.

The third solution starts from the people whose land is acquired. For the remaining agricultural land that households possess, they should boldly apply new forms of production with high efficiency. People should endeavor to improve land to cultivate crops. They should also spend part of the compensation money on training to develop their own business or labor export (in the case of labor under 35 years of age), or traditional craft industries (in the case of labor above 35 years of age).

This research has some limitations. The data used in this study came from 50 households out of 310 affected households. Information will be more useful when the research area and time are extended. This study deals with the income and employment of households after losing land. Remaining issues, such as food shortage and environmental impacts, will be the driving force for us in future studies. In the course of the study, we found an incomprehensibility in the process of land acquisition and compensation, as well as in attracting investors to the project. Therefore, we will study these aspects in our future research.

Author Contributions: Conceptualization, T.T.N., and G.H.; Methodology, T.T.N.; Formal analysis, T.T.N., and G.H.; Investigation, T.L.N., Data curation, T.T.N., and T.L.N.; Writing-original draft preparation, T.T.N., Visualization, T.T.N., and G.H.

Acknowledgments: The authors would like to thank Stipendium Hungaricum Scholarship programme for supporting our research and the leaders of Vietnamese State Agencies for providing statistical data. The authors would also like to thank the 50 families who have enthusiastically assisted during the interview process. Lastly, the authors' gratitude goes to Tamás Kovalcsik who is a Ph.D student in the Department of Economic and Social Geography at the University of Szeged for instructing Tran Tuan NGUYEN to make the map by ArcGIS.

Conflicts of Interest: The authors declare no conflict of interest.

\section{References}

1. Parwez, S.; Sen, V. Special economic zone, land acquisition, and impact on rural india. Emerg. Econ. Stud. 2016, 2, 223-239. [CrossRef]

2. Tan, R.; Beckmann, V.; Van den Berg, L.; Qu, F. Governing farmland conversion: Comparing China with the Netherlands and Germany. Land Use Policy 2009, 26, 961-974. [CrossRef]

3. Azadi, H.; Ho, P.; Hasafiati, L. Agricultural land conversion drivers: A comparison between less developed, developing and developed countries. Land Degrad. Dev. 2011, 22, 596-604. [CrossRef]

4. Bryceson, D.F. Deagrarianization and rural employment sub-Saharan Africa: A sectoral perspective. World Dev. 1996, 24, 97-111. [CrossRef]

5. Lichtenberg, E.; Ding, C. Assessing farmland protection policy in China. Land Use Policy 2008, $25,59-68$. [CrossRef]

6. Firman, T. Rural to urban land conversion in Indonesia during boom and bust periods. Land Use Policy 2000, 17, 13-20. [CrossRef]

7. Ho, S.P.; Lin, G.C. Converting land to nonagricultural use in China's coastal provinces: Evidence from Jiangsu. Mod. China 2004, 30, 81-112. [CrossRef]

8. Van Suu, N. Agricultural land conversion and its effects on farmers in contemporary Vietnam. Focaal-Eur. J. Anthropol. 2009, 54, 106-113. [CrossRef] 
9. Shah, A.; Nandani, D.; Joshi, H. Marginalization or Mainstreaming? Evidence from Special Economic Zones in Gujarat; Working Paper No. 210; Gujarat Institute of Development Research: Ahmedabad, India, 2012.

10. Ghatak, M.; Mitra, S.; Mookherjee, D.; Nath, A. Land acquisition and compensation in singur: What really happened? Econ. Political Wkly. 2013, 48, 32-44.

11. Trung, D. Operation Situation and Establishment of IZs and EZs in the First 6 Months of 2018. Available online: http://www.mpi.gov.vn/Pages/tinbai.aspx?idTin=40254\&idcm=188 (accessed on 21 January 2019).

12. Tuyen, T.Q. Farmland Acquisition and Household Livelihoods in Hanoi's Peri-Urban Areas. Ph.D. Thesis, The University of Waikato, Hamilton, New Zealand, 2013.

13. General Statistical Organization of Vietnam (GSO). Available online: https://www.gso.gov.vn/default.aspx? tabid=714 (accessed on 19 January 2019).

14. Nguyen, T.H.T. Conversion of Agricultural Land and Its Impact on Peasants in Hanoi Suburbs During Rapid Urbanization: A Case Study of Me Tri Commune; Jimburn Chiri/Human Geography: Kyoto, Japan, 2011; Volume 63, pp. 1-17.

15. Nguyen, P.; van Westen, A.; Zoomers, A. Compulsory land acquisition for urban expansion: Livelihood reconstruction after land loss in Hue's peri-urban areas, Central Vietnam. Int. Dev. Plan. Rev. 2017, 39, 99-121. [CrossRef]

16. Thanh, M. Transition of Labour Structure in Rural Areas After Land Acquisition. Available online: http://www.tapchicongsan.org.vn/Home/Nghiencuu-Traodoi/2009/1003/Ve-chuyen-doi-co-cau-laodong-nong-thon-sau-thu-hoi.aspx (accessed on 24 January 2019).

17. Fazal, S. The Need for preserving farmland: A case study from a predominantly agrarian economy (India). Landsc. Urban Plan. 2001, 55, 1-13. [CrossRef]

18. Ministry of Statistics and Programme Implementation. Sector-Wise Contribution of GDP of India. Available online: http://statisticstimes.com/economy/sectorwise-gdp-contribution-of-india.php (accessed on 24 February 2019).

19. The World Bank. Employment in Agriculture (\% of Total Employment) (Modeled ILO Estimate). Available online: https://data.worldbank.org/indicator/sl.agr.empl.zs?name_desc=false (accessed on 16 February 2019).

20. Hoai, T. Quang Binh Industrial Zones and Economic Zones: The Key to Attracting Investment Capital. Available online: http://enternews.vn/cac-khu-cong-nghiep-khu-kinh-te-quang-binh-trong-diem-hut-vondau-tu-113524.html (accessed on 6 January 2019).

21. People's Committee of Quang Binh province. Decision No. 2221/QD-CT on Approving the Investment Project on Construction of the Northwest Quan Hau Industrial Park Infrastructure Project; People's Committee of Quang Binh province: Quang Binh, Vietnam, 2012.

22. People's Committee of Quang Binh province. Decision No. 1518/QD-UBND on Approving the Investment Project on Construction of Roads for the Northwest Quan Hau Industrial Park (Phase 1); People's Committee of Quang Binh province: Quang Binh, Vietnam, 2011.

23. Hong Thieu. Quang Binh: The Northwest Quan Hau Industrial Park Nearly 10 Years of Construction is Still Unfinished. Available online: https://baotainguyenmoitruong.vn/ban-doc/quang-binh-khu-cong-nghieptay-bac-quan-hau-gan-10-nam-xay-dung-van-con-dang-do-1260953.html (accessed on 20 January 2019).

24. People's Committee of Quang Binh province. Decision No. 05/2009/QD-UBND on Regulations of Compensation, Support and Resettlement Policies When the State Acquires Land in Quang Binh Province; People's Committee of Quang Binh province: Quang Binh, Vietnam, 2009.

(C) 2019 by the authors. Licensee MDPI, Basel, Switzerland. This article is an open access article distributed under the terms and conditions of the Creative Commons Attribution (CC BY) license (http://creativecommons.org/licenses/by/4.0/). 